\title{
EVALUASI SURVEILANS COVID-19 DI PUSKESMAS BULELENG I KABUPATEN BULELENG
}

\author{
Ni Luh Putu Seri Wardani ${ }^{1}$, I Nyoman Purnawan ${ }^{2}$, Made Nyandra ${ }^{3}$ \\ 1,2,3 Fakultas Ilmu Kesehatan, Sains Dan Tekonologi, Universitas Dhyana Pura Badung Bali
}

\begin{tabular}{|c|c|}
\hline Article Info & ABSTRACT \\
\hline $\begin{array}{l}\text { Article history: } \\
\text { Received 22-08-2021 } \\
\text { Revised 07-09-2021 } \\
\text { Accepted 15-09-2021 }\end{array}$ & $\begin{array}{l}\text { Buleleng Regency ranks third as the area with a high risk of spreading covid- } \\
19 \text { in Bali, Buleleng Regency as a high-risk area of COVID-19 transmission, } \\
\text { it's categorized by a team of experts of the National Task Force, in Buleleng } \\
\text { Regency Puskesmas Buleleng I rank first in the number of COVID-19 cases, } \\
\text { this research has the aim to evaluate aspects of COVID-19 surveillance } \\
\text { input in Buleleng Health Center I. The research design used is descriptive }\end{array}$ \\
\hline $\begin{array}{l}\text { Keywords: } \\
\text { Evaluation, } \quad \text { Surveillance of } \\
\text { COVID-19, Input Aspects }\end{array}$ & $\begin{array}{l}\text { research with a qualitative approach. The conclusion of this study is that } \\
\text { man is not under the guidelines; the method under the guidelines is the } \\
\text { availability of guidelines for prevention and prevention of COVID-19 } \\
\text { Disease Rev.5; the allocation of funds has not been in accordance with the } \\
\text { guidelines because the amount of funds available does not match the } \\
\text { increase in cases that occur but the source of funds is appropriate; facilities } \\
\text { and infrastructure are only problems of the internet network that have not } \\
\text { been in accordance with the guidelines; The advice given from the research } \\
\text { results is to work with health academics for human resource improvement } \\
\text { activities, make position analysis to meet the needs of epidemiologists, } \\
\text { improve surveillance facilities while in the field. }\end{array}$ \\
\hline
\end{tabular}

\begin{abstract}
Abstrak
Kabupaten Buleleng menempati urutan ketiga daerah dengan risiko tinggi penyebaran covid-19 di Bali, Kabupaten Buleleng sebagai daerah berisiko tinggi penularan COVID-19, itu dikategorikan oleh tim ahli Gugus Tugas Nasional, di Puskesmas Kabupaten Buleleng Buleleng I menempati urutan pertama jumlah kasus COVID-19, penelitian ini bertujuan untuk mengevaluasi aspek input surveilans COVID-19 di Puskesmas Buleleng I. Desain penelitian yang digunakan adalah penelitian deskriptif dengan pendekatan kualitatif. Hasil dari penelitian ini adalah bahwa aspek manusia tidak sesuai dengan buku pedoman; metode yang di gunakan sudah sesuai dengan buku pedoman seperti tersedianya pedoman pencegahan dan evaluasi pencegahan Penyakit COVID-19, alokasi dana belum sesuai dengan pedoman karena jumlah dana yang tersedia tidak sesuai dengan peningkatan kasus yang terjadi namun untuk sumber dana sudah sesuai; sarana dan prasarana hanya masalah jaringan internet yang belum sesuai dengan pedoman; Saran yang dapat diberikan dari hasil penelitian adalah bekerja sama dengan akademisi kesehatan untuk kegiatan peningkatan sumber daya manusia, membuat analisis posisi untuk memenuhi kebutuhan ahli epidemiologi, meningkatkan fasilitas surveilans selama di lapangan.
\end{abstract}

\author{
Corresponding Author: \\ Ni Luh Putu Seri Wardani \\ Program Studi Ilmu Kesehatan Masyarakat \\ Fakultas Ilmu Kesehatan, Sains Dan Tekonologi \\ Universitas Dhyana Pura Badung
}

Email: wardani.dwipayana@gmail.com 


\section{PENDAHULUAN}

Pada awal 2020, dunia dikejutkan dengan mewabahnya pneumonia baru yang bermula dari Wuhan, Provinsi Hubei yang kemudian menyebar dengan cepat ke lebih dari 190 negara dan teritori. Wabah ini diberi nama coronavirus disease 2019 (COVID-19) yang disebabkan oleh Severe Acute Respiratory Syndrome Coronavirus-2 (SARS-CoV-2). Penyebaran penyakit ini telah memberikan dampak luas secara sosial dan ekonomi. Sejak kasus pertama di Wuhan, terjadi peningkatan kasus COVID-19 di China setiap hari dan memuncak diantara akhir Januari hingga awal Februari 2020. Awalnya kebanyakan laporan datang dari Hubei dan provinsi di sekitar, kemudian bertambah hingga ke provinsiprovinsi lain. Pada tanggal 11 Maret 2020 Organisasi Kesehatan Dunia (WHO) secara resmi mengumumkan wabah COVID-19 sebagai pandemi global karena dalam waktu kurang dari 3 bulan, COVID-19 telah menginfeksi 126.000 orang di 123 negara dari Asia, Eropa, AS hingga Afrika selatan, data terakhir global di seluruh dunia menunjukkan 45.608.024 kasus terkonfirmasi dengan jumlah kematian 118.913 orang .

COVID-19 pertama dilaporkan di Indonesia pada tanggal 2 Maret 2020 sejumlah dua kasus, data 31 Oktober 2020 menunjukkan 406.945 kasus terkonfirmasi dengan jumlah kematian 13.782 orang (CFR 3,39\%) dengan angka kejadian : 148,78 per 100.000 jumlah penduduk [1]. Di Propinsi Bali dilaporkan kasus akumulatif COVID -19 sebanyak 11.712 orang terkonfirmasi dengan jumlah kematian 385 orang (CFR 3,28\%) dengan tingkat kesembuhan 90,17\% [2]. Kabupaten Buleleng menempati urutan ke 3 terbanyak kasus COVID-19 yaitu dengan 1032 orang terkonfirmasi dengan jumlah kematian 53 orang (CFR 5,14\%) dengan tingkat kesembuhan 90,79\% dan masih masih dalam perawatan $4,07 \%[3]$

Mengurangi penyebaran virus Covid-19 mendorong pemerintah untuk berupaya melakukan pengendalian Covid-19 dengan melakukan surveilansepidemiologi [4][5]. Pelaksanaan surveilans epidemiologi merupakan salah satu upaya untuk mengatasi masalah penyakit menular [6][7].Surveilans epidemiologi merupakan kegiatan analisis secara sistematis dan terus menerus terhadap penyakit atau masalah-masalah kesehatan dan kondisi yang mempengaruhi terjadinya peningkatan dan penularan penyakit atau masalah kesehatan tersebut agar dapat melakukan tindakan penanggulangan secara efektif dan efesien melalui proses pengumpulan data, pengolahan dan penyebaran informasi epidemiologi kepada penyelenggara program kesehatan [8][9]. 
Kegiatan surveilans Covid-19 dilakukan terutama untuk menemukan kontak erat, jika ditemukan satu kasus konfirmasi COVID-19 maka dinyatakan sebagai KLB [10] . Surveilans Covid-19 dilakukan dengan tujuan mengetahui besar masalah dan mencegah penyebaran yang lebih luas[11][12]. Secara khusus tujuan surveilans Covid-19 yaitu untuk mengetahui karakteristik Covid-19, gejala klinis dan virus, mengidentifikasi faktor risiko, mengidentifikasi kasus tambahan dan memberikan rekomendasi upaya penanggulangan [13].

Penelitian Surveilans sudah pernah dilakukan yang menilai pada atribut surveilans dilakukan oleh [14][15][16]. hasil penelitian [14]menunjukkan bahwa sistem surveilans Japanese Encephalitis tidak sederhana, tidak fleksibel, akseptabilitasnya rendah, tidak sensitive, nilai prediktif positifnya rendah dan kualitas datanya rendah. Dalam Studi [17], menganalisis penilaian evaluasi sistem surveilans campak di Dinas Kesehatan Kabupaten Bangkalanmasih dinilai kurang. Hal ini menunjukkan bahwa kekurangan pelaksanaan sistem surveilans masih banyak ditemukan dalam komponen input dan proses kegiatan surveilans terutama di tingkat puskesmas. Hasil yang sama juga dihasilkan [18] menilai sistem surveilans Japanese Encephalitis di Dinas Kesehatan Provinsi Bali belum berjalan secara efektif dan efisien. Bahwa pada komponen input sistem surveilans terutama pada petugas surveilans belum sesuai dengan Kepmenkes RI Nomor 129 tahun 2008, sedangkan untuk evaluasi atribut sistem surveilans adalah tidak fleksibel, tidak tepat waktu, dan memiliki kualitas data rendah.

Dinilai masih kurangnya pada aspek input dalam penelitian terdahulu menjadi dasar penelitian ini untuk fokus pada aspek input dalam manajemen surveilans COVID-19 yang meliputi 5M (man, money, material, method, dan market). Proses dan output tidak menjadi prioritas utama dalam penelitian ini, karena komponen input merupakan sumber daya utama yang menjadi penentu dasar terhadap data hasil surveilans sehingga lebih diprioritaskan untuk dievaluasi [19]. Yang menjadi pembaharuan dalam penelitian ini yaitu menggunakan dasar penilaian surveilans yang baru yaitu Peraturan Menteri Kesehatan Republik Indonesia Nomor 45 Tahun 2014 tentang Penyelenggaraan Sistem Surveilans Kesehatan. Tujuan dari penelitian ini adalah untuk mengevaluasi aspek input surveilans COVID-19 di Puskesmas Buleleng I sesui dengan Kepmenkes 2014.

\section{METODE PENELITIAN}


Penelitian ini adalah penelitian kualitatif dengan pendekatan deskriptif karena peneliti ingin menggambarkan keadaan di tempat penelitian. Penelitian kualitatif adalah prosedur penelitian yang menghasilkan data deskriptif berupa kata-kata tertulis atau lisan dari orang-orang dan perilaku yang dapat diamati[20].Tehnik pengumpulan data dalam penelitian ini yaitu dengan tehnik wawancara Dalam penelitian ini penetapan informan menggunakan teknik purposive sampling (sampel bertujuan), karena dalam penelitian kualitatif tidak terdapat sampel acak, tetapi sampel bertujuan. Tehnik purposive sampling atau sampel bersyarat adalah pemilihan sampel berdasarkan karakteristik atau kriteriakriteria tertentu yang sesuai dan tepat berdasarkan kebutuhan data dalam melakukan penelitian[21]. Purposive sample dalam penelitian ini adalah mereka (para informan) yang terlibat secara teknis dan berhubungan langsung dengan program yaitu petugas surveilans Puskesmas Buleleng I berjumlah 2 orang, Kepala Puskesmas Buleleng I, petugas pelacakan kontak, Pejabat Pelaksana Tehnis Kegiatan (PPTK) dan Petugas promosi Kesehatan berjumlah 5 orang.

\section{HASIL DAN PEMBAHASAN}

\subsection{Hasil Penelitian}

Berdasarkan hasil wawancara dengan informan penelitian maka hasil wawancara tersebut selanjutnya dilakukan penilaian keakuratan data dengan tehnik triangulasi.

1. Man (Sumber Daya Manusia)

Sumber daya manusia adalah merupakan hal yang terpenting yang perlu diperhatikan dalam kegiatan surveilans. Menurut Kemenkes RI (2014) menyebutkan bahwa sumber daya manusia yang dimaksud disini adalah jumlah tenaga surveilans, tenaga surveilans yang terlatih untuk system surveilans, kualifikasi tenaga surveilans, tenaga pengelola program terlatih di kabupaten/kota dan tenaga laboratorium yang terlatih.

Berdasarkaan hasil wawancara dengan Bapak Kepala Puskesmas Buleleng I (dr Gede Purnamawan ) menyerbutkan bahwa "menurut saya tenaga Surveilans sudah memadai dan sesuai dengan standar". Aturan Dinkes (2020) menyebutkan standar Surveilans Covid-19 yang harus dimiliki setiap puskesmas adalah satu. Hal ini juga dibenarkan oleh petugas surveilans yaitu Komang Yuni Trisnawati (surveilans Covid -19) yang menyebutkan sesuai aturan cukup satu yang menangani, namun dalam aplikasinya jika banyak wilayah yang di teridentifikasi covid-19 saat 
itu petugas surveilans covid -19 merasa kewalahan. Disebutkan pula bahwa Puskesmas memiliki dua surveilans dengan tupoksi yang berbeda yaitu surveilans program dan surveilans Covid-19. Berdasarkan hasil wawancara dengan Pihak tracer yaitu Wayan Susanti menilai selama ini dalam operasionalnya jumlah surveilans masih cukup dan memadai.

Berkaitan dengan kualifikasi tenaga surveilans covid-19 saat ini di Puskesmas Buleleng I masih belum sesuai dengan kualifikasinya. Kepala Puskesmas Buleleng I menyebutkaan bahwa " tenaga surveilans yang kami miliki masih belum sesuai dengan kualifikasi karena tenaga surveilans kami tidak memiliki dasar pendidikan epidemiologi. Saat ini, petugas surveilans yang kami miliki masih belum sesuai pendidikan dasar yang dimilikinya karena di puskesmas tenaga sumberdaya manusia yang dominan adalah pendidikan dasar kebidanan. Seperti halnya surveilans program yang ditugaskan memiliki basic pendidikan kesehatan lingkungan serta petugas surveilans covid memiliki berbasic kebidanan. Walaupun petugas surveilans tidak memiliki pendidikan epidemiologi namun semua petugas surveilans sudah mendapatkan pembelajaran atau pelatihan tentang surveilans covid19. Petugas surveilans kami juga sudah mendapatkan orientasi langsung dari Kemenkes melalui virtual tentang surveilans covid-19”. Pendapat tersebut dibenarkan oleh petugas surveilans yang menyatakan bahwa "saya tidak memiliki kualifikasi yang sesuai sebagai tenaga surveilans namun karena ini merupakan penunjukan langsung dari Kepala Puskesmas Buleleng I dan karena saya sudah mendapatkan pembelajaran atau pelatihan tentang surveilans covid-19, maka semua tugas surveilans dapat saya lakukan dengan baik"(Komang Yuni Trisnawati). Hasil wawancara dengan tenaga tracer menyebutkan bahwa surveilans yang ditugaskan menurut saya sudah sesuai dengan kebutuhan dan memiliki kemampuan serta pemahaman tentang Surveilans, sehingga mudah untuk menjaga kordinasi dan komunikasi (Heny Prisilia Risma Dewi). Berkaitan dengan tenaga pengelola program terlatih surveilans covid- 19 di Kabupaten Buleleng disebutkan oleh pihak informan belum memadai karena selama ini hanya dilakukan secara virtual dengan pihak kemenkes.

2. Material-Machine (Sarana dan Prasarana) 
Menurut Kemenkes RI (2014) menyebutkan sarana dan prasarana pendukung kegiatan surveilans meliputi komputer, software, layanan internet, ATK seperti pulpen, kertas, tinta, buku pedoman/petunjuk teknis pelaksanaan surveilans epidemiologi, formulir pengumpulan data surveilans, surveillance kits berupa calculator scientific, kertas grafik, formulir perekam, pengolahan, serta laporan telpon dan faksimile atau alat komunikasi lainnya. Berdasarkan wawancara dengan beberapa informan penelitian menyebutkan bahwa sarana dan prasarana yang dimiliki oleh Puskesmas Buleleng I dalam pelaksanaan surveilans sudah sesuai dengan Peraturan Menteri Kesehatan Republik Indonesia Nomor 45 Tahun 2014 tentang Penyelenggaraan Sistem Surveilans Kesehatan. Pernyataan ini sejalan dengan penjelasan Kepala Puskesmas yang menyebutkan bahwa sarana dan prasarana yang digunakan oleh petugas surveilans sudah terpenuhi dan tidak ada kendala. Hal ini, disebabkan karena disupport oleh banyak pihak seperti LSM, Yayasan, maupun dari dana APBD. Pendapat tersebut dibenarkan oleh petugas surveilans dan tracer bahwa semua sarana dan prasarana yang digunakan sudah memadai aktivitas surveilans. Terkait dengan buku pedoman dan petunjuk teknis pelaksanaan surveilans epidemiologi sudah tersedia lengkap. Begitupula halnya dengan ketersediaan formulir pengumpulan data surveilans covid-19, perlengkapan seminar, ketersediaan alat transportasi, ketersediaan perlengkapan surveilans serta ketersediaan alat komunikasi sudah memadai dan menunjang dari aktivitas surveilans. Pedapat ini disampaikan oleh semua narasumber baik kepala puskesmas, petugas surveilans serta petugas tracer. Dalam hasil wawancara pihak surveilans menerangkan adanya suatu kesulitan dalam pelaporan yang harus dilakukan segera dengan online yaitu terbatasnya jaringan wifi di lokasi tertentu sehingga pada publik area petugas menggunakan wifi pribadi.

\section{Method (metode)}

Menurut Peraturan Menteri Kesehatan Republik Indonesia Nomor 45 Tahun 2014 tentang Penyelenggaraan Sistem Surveilans Kesehatann menyebutkan metode dalam pelaksanaan kegiatan surveilans meliputi pedoman pelaksanaan suatu kegiatan surveilans, juklak-juknis dan surat keputusan pelaksanaan suatu kegiatan. Hasil wawancara dengan pihak informan terkait dengan metode dapat dijelaskan bahwa di Puskesmas Buleleng I sudah memiliki buku pedoman pelaksanaan kegiatan 
surveilans covid-19 berupa formulir pengumpulan data surveilans covid-19 serta sudah tersedianya juklak dan juknis surveilans covid-19. Berdasarkan hasil wawancara dengan Kepala Puskesmas Buleleng I menyebutkan bahwa dalam pelaksanakan kegiatan surveilans covid 19 serta penunjukan petugas surveilans dilakukan dengan penunjukan langsung oleh Kepala Puskesmas Bulelelng I. Hal ini, dibenarkan oleh petugas surveilans menurut Komang Yuni Trisnawati menyatakan bahwa "memang benar petugas surveilans covid 19 dilakukan dengan petunjukan langsung oleh kepala Puskesmas Bulelelng I dengan syarat dan ketentuan tertentu seperti ikut serta dalam pelatihan surveilans". Pihak Surveilans juga menyebutkan bahwa meski sudah memiliki juklak dan juknis namun surveilans tidak memiliki hard copy laporan survailans. Laporan yang dimiliki hanya berbentuk soft copy, hal ini dikarenakan terlalu sering adanya revisi sehingga diambil poin penting perubahan disetiap revisian juknis yang kemudian disebarkan melalui Whatsap Group puskesmas.

\section{Money (Sumber Dana)}

Ditjen P2PL (2003) menyebutkan yang dimaksud dengan sumber dana dalam pelaksanaan kegiatan surveilans meliputi dana program APBD Kabupaten/Kota, APBD provinsi, APBN dan dana bantuan yang berasal dari LSM/Swasta nasional dan daerah, swadaya masyarakat, dan bantuan Luar Negeri. Berdasarkan hasil wawancara dengan Kepala Puskesmas Buleleng I terkait dengan sumber dana yang tersedia dalam pelaksanaan program surveilans covid-19 dikatakan bahwa "Terkait dengan dana khusus kami di Puskesmas Buleleng I yang digunakan untuk program surveilans bersumber dari dana bantuan operasional kesehatan yaitu dana alokasi khusus bidang kesehatan puskesmas yang dikelola oleh puskesmas sendiri yang di peruntukkannya $40 \%$ dari dana tersebut dipergunakan untuk kegiatan tracing. Dana tersebut dapat diperuntukkan untuk membeli bahan habis pakai dan dapat juga dipergunakan untuk uang transport petugas tracing. Dana yang diberikan diupayakan cukup digunakan dalam operasionalnya". Tenaga surveilans sering mengeluhkan kekurangan dana dalam menunjang aktivitasnya. Hal tersebut dibenarkan oleh petugas surveilans dan tracer yang menjelaskan bahwa menurut mereka dana $40 \%$ tersebut masih belum cukup untuk menutupi semua pengeluaran petugas dan bahkan petugas masih menggunakan dana sendiri dalam pengiriman laporan online. 


\section{Market (sasaran)}

Menurut Kemenkes RI (2014) menyebutkaan bahwa sasaran (market) dari setiap manajemen surveilans epidemiologi suatu penyakit tidak sama, tergantung pada siapa yang membutuhkan informasi yang dihasilkan dari pelaksanaan kegiatan surveilans. Berdasarkan hasil wawancara terkait dengan sasaran kepada beberapa informan penelitian tentang pentingnya laporan surveilans dan menurut mereka Hasil laporan surveilans covid -19 ini sangat dibutuhkan sebagai informasi penting untuk pihak terkait. Seperti yang disampaikan oleh kepala Puskesmas Buleleng I menyatakan bahwa ada pihak internal dan eksternal yang membutuhkan laporan ini yaitu pihak internal seperti kepala puskesmas, Kabid kesehatan masyarakat, pemberdayaan masyarakat dan Dinas Kesehatan serta pihak external yang membutuhkan informasi ini yaitu Direktur Rumah Sakit, kader, kepolisian, camat, dan TNI. Pernyataan tersebut diperjelas oleh petugas surveilans yang menjelaskan bahwa hasil surveilans covid-19 dipandang sangat penting dan dibutuhkan oleh banyak pihak untuk memagari dan mebatasi aktivitas masyarakat serta masyarakat jadi bisa lebih waspada. Selain itu, hasil surveilans covid-19 ini juga dapat digunakan dalam proses pengambilan keputusan puskesmas terkait dengan penanganan covid-19 yaitu dengan memberikan perhatian khusus dalam penanganan covid di daerah tersebut.

\section{b. Pembahasan}

Berdasarkan Kemenkes RI (2014) menyebutkan bahwa untuk menunjang kegiatan surveilans epidemiologi dapat berjalan sesuai dengan harapan, maka diperlukan adanya manajemen kegiatan yang baik mulai dari perencanaan hingga evaluasi. Manajemen surveilans epidemiologi dilakukan melalui pendekatan sistem yaitu input, proses, dan output. Pendekatan input adalah merupakan sumber utama yang harus ada sebelum dilanjutkan pada proses. Input memegang peranan yang sangat penting jika input bagus dengan proses yang bagus akan menghasilkan hasil yang bagus pula dan begitu sebaliknya. Pendekatan input dalam kegiatan surveilans epidemiologi terdiri atas $5 \mathrm{M}$ (man, method, money, material-machine, dan market).

Berdasarkan hasil wawancara mendalam dengan beberapa narasumber menggambarkan bahwa 5M yang ada pada Puskesmas Buleleng 1 masih belum sesuai 
dengan indicator yang tertuang dalam Peraturan Menteri Kesehatan Republik Indonesia Nomor 45 Tahun 2014 tentang Penyelenggaraan Sistem Surveilans Kesehatan yang masih perlu dimaksimalkan. Aspek input surveilans COVID-19 yang pertama yaitu sumber daya manusia. Sumber daya manusia adalah merupakan hal terpenting yang harus dimiliki untuk mencapai tujuan organisasi atau perusahaan. Aspek sumber daya manusia diukur dengan jumlah tenaga surveilans, tenaga surveilans yang terlatih untuk system surveilans, kualifikasi tenaga surveilans, tenaga pengelola program terlatih di kabupaten/kota, tenaga laboratorium yang terlatih. Berdasarkan hasil wawancara dengan Kepala Puskesmas Buleleng I (dr Gede Purnamawan) menjelaskan bahwa puskesmas saat ini memiliki satu tenaga surveilans Covid-19. Terkait dengan jumlah tenaga surveilans sudah memadai dan belum sesuai dengan standar.

Aturan Dinkes (2020) menyebutkan standar Surveilans Covid 19 yang harus dimiliki setiap puskesmas adalah satu. Hal ini juga sesuai dengan hasil wawancara petugas surveilans yang menyebutkan sesuai aturan cukup satu yang menangani namun dalam aplikasinya jika banyak wilayah yang di teridentifikasi covid-19, saat itu petugas surveilans covid -19 merasa kewalahan. Penilaian kualifikasi tenaga surveilans covid19 yang dimiliki oleh Puskemas Buleleng I masih belum sesuai dengan kualifikasinya. Disebutkan dalam wawancara baik dengan kepala puskesmas maupun petugas surveilans memang membenarkan bahwa saat ini tenaga surveilans masih belum sesuai dengan kualifikasinya yaitu memiliki dasar pendidikan epidemiologi. Petugas surveilans puskesmas saat ini yang bertugas memiliki pendidikan dasar kebidanan. Hal ini dikarenakan puskesmas Buleleng I memiliki sumberdaya manusia yang dominan pendidikan dasar kebidanan. Untuk menjaga kualitas surveilans Puskesmas Buleleng I mewajibkan petugas surveilans yang ditunjuk mendapatkan pembelajaran atau pelatihan tentang surveilans covid-19 serta mendapatkan orientasi langsung dari Kemenkes meski melalui virtual tentang surveilans covid-19 untuk mengoptimalkan pekerjaannya. Dengan demikian kualitas tenaga surveilans dapat optimal meski tidak memiliki dasar pendidikan epidemiologi.

Surveilans tidak dapat terlepas dari petugas tracer karena dua bagian tersebut saling melengkapi. Berdasarkan hasil wawancara dengan petugas tracer juga menjelaskan tidak mengalami hambatan dalam berkordinasi dengan pihak Surveilans serta dinilai petugas Surveilans yang ditunjuk mampu memahami dan mengerti setiap 
tugas-tugasnya. Berkaitan dengan tenaga pengelola program terlatih surveilans covid19 di Kabupaten Buleleng disebutkan oleh pihak informan belum memadai karena selama ini hanya dilakukan secara virtual dengan pihak kemenkes.

Sarana dan prasarana juga merupakan input yang tidak kalah pentingnya dengan SDM. Menyebutkan sarana dan prasarana pendukung kegiatan surveilans meliputi komputer, software, layanan internet, ATK seperti pen, kertas, dan tinta, buku pedoman/petunjuk teknis pelaksanaan surveilans epidemiologi, formulir pengumpulan data surveilans, Surveillance kits dan laporan. Semua sarana dan prasarana yang dimaksud sudah dapat dipenuhi oleh Puskesmas Buleleng I. Berdasarkan hasil wawancara tengan kepala Puskesmas Buleleng I menyebutkan bahwa sarana dan prasarana yang dimiliki oleh Puskesmas Buleleng I dalam pelaksanaan surveilans sudah memadai. Terkait dengan sarana dan prasarana yang dibutuhkan oleh petugas surveilans tidak terlepas dari dukungan banyak pihak.

Disebutkaan oleh informan bahwa sarana dan prasarana yang digunakan adalah merupakan dukungan oleh banyak pihak seperti LSM,Yayasan, maupun dari dana APBD. Pernyataan ini, dibenarkan oleh petugas surveilans dan tracer bahwa semua sarana dan prasarana yang digunakan sudah memadai aktivitas surveilans. Selain sarana dan prasarana yang dimaksud di atas, pihak surveilans pada Puskesmas Buleleng I juga sudah dilengkapi dengan ketersediaan buku pedoman dan petunjuk teknis pelaksanaan surveilans epidemiologi. Seperti yang disampaikan oleh Kepala Puskesmas Buleleng I menjelaskan bahwa ketersediaan buku pedoman ini dianggap sangat penting untuk memperjelas dan memperlancar kegiatan surveilans.

Sumber informan penelitian juga menyebutkan bahwa Puskesmas Buleleng I memiliki ketersediaan formulir pengumpulan data surveilans covid-19, ketersediaan perlengkapan seminar, ketersediaan alat transportasi, ketersediaan perlengkapan surveilans serta ketersediaan alat komunikasi sudah memadai dan menunjang dari aktivitas surveilans. Pedapat ini disampaikan oleh semua pihak narasumber baik kepala puskesmas, petugas surveilans serta petugas tracer. Meski sarana dan prasarana yang digunakan oleh petugas surveilans sudah menunjang namun pihak surveilans menerangkan bahwa masih merasa ada penghambat dalam pelaporan. Ada suatu laporan yang sifatnya segera untuk dilaporkan oleh surveilans diluar puskesmas atau dilapangan yang membutuhkan jaringan wifi yang memadai. Surveilans merasa 
bahwa masih terbatasnya jaringan wifi di lokasi tertentu sehingga pada publik area petugas menggunakan fasilitas pribadi.

Metode juga merupakan bagian input yang harus dipertikan demi menghasilkan output yang optimal. Metode dalam kegiatan surveilans meliputi pedoman pelaksanaan suatu kegiatan surveilans, juklak-juknis, surat keputusan pelaksanaan suatu kegiatan. Hasil wawancara dengan pihak informan terkait dengan metode dapat dijelaskan bahwa, di Puskesmas Buleleng I sudah memiliki metode yang jelas dan sesuai dengan aturan yang berlaku. Puskesmas Buleleng I sudah memiliki buku pedoman pelaksanaan kegiatan surveilans covid-19 berupa formulir pengumpulan data surveilans covid-19 serta sudah memiliki juklak dan juknis surveilans covid-19. Petugas surveilans menjelaskan bahwa setiap aktivitas yang menyangkut surveilans covid-19 selalu menjalankan sesuai dengan buku pedoman serta juklak dan juknis kegiatan surveilans.

Berdasarkan hasil wawancara dengan Kepala Puskesmas Buleleng I menyebutkan bahwa untuk penunjukan petugas surveilans dilakukan dengan penunjukan langsung oleh Kepala Puskesmas Bulelelng I. Penunjukan langsung yang dilakukan oleh kepala Puskesmas Bulelelng I harus memenuhi syarat dan ketentuan tertentu seperti sudah mengikuti pelatihan surveilans. Ketersediaan payung hukum surveilans Covid-19 yang dimiliki pastinya sudah sangat jelas karena semuanya diatur oleh Kemenkes. Pihak Surveilans juga menyebutkan bahwa, meski sudah memiliki juklak dan juknis namun surveilans tidak memiliki hard copy serta hanya mempunyai soft copy. Hal ini dikarenakan terlalu sering adanya revisi, sehingga diambil poin penting perubahan disetiap revisian juknis yang kemudian disebarkan melalui Whatsap Group puskesmas.

Lancar tidaknya kegiatan surveilans sangat tergantung pada dukungan sumber dana. Sumber dana dalam pelaksanaan kegiatan surveilans dapat meliputi dana program APBD Kabupaten/Kota, APBD provinsi, APBN dan dana bantuan yang berasal dari LSM/Swasta nasional dan daerah, swadaya masyarakat, dan bantuan Luar Negeri. Berdasarkan hasil wawancara dengan pihak informan terkait dengan sumber dana yang tersedia dalam pelaksanaan program surveilans covid-19 bersumber dari dana bantuan operasional kesehatan yaitu dana alokasi khusus bidang kesehatan puskesmas yang dikelola oleh puskesmas sendiri yang di peruntukkannya $40 \%$ dari dana tersebut dipergunakan untuk kegiatan tracing.Dana tersebut dapat diperuntukkan 
untuk membeli bahan habis pakai dan dapat juga dipergunakan untuk uang transport petugas tracing. Dana ini harus dicukupkan untuk membiayai segala biaya operasional surveilans. Menurut Kepala Puskesmas Buleleng I ini menjelaskan "kami hanya mampu memberikan dana khusus $40 \%$ tersebut untuk menunjang kegiatan surveilans. Sehingga pihak surveilans mampu mengelola dana tersebut untuk operasionalnya". Dalam sudut pandang surveilans menyebutkan dana yang dianggarkan dinilai masih belum cukup untuk menutupi semua pengeluaran petugas dan bahkan petugas masih menggunakan dana pribadi dalam pengiriman laporan online.

Sasaran dari setiap manajemen surveilans epidemiologi suatu penyakit tidaklah sama, tergantung pada siapa yang membutuhkan informasi yang dihasilkan dari pelaksanaan kegiatan surveilans. Berdasarkan hasil wawancara dengan beberapa pihak informan menyebutkan bahwa hasil laporan surveilans covid -19 sangatlah penting bagi banyak pihak. Pihak yang menggunakan hasil laporan surveilans covid -19 sangatlah banyak baik dari pihak internal maupun dari pihak eksternal. Pihak internal yang membutuhkan laporan surveilans adalah kepala puskesmas, Kabid kesehatan masyarakat, pemberdayaan masyarakat dan Dinas Kesehatan.

Hasil surveilans covid-19 untuk pihak internal dapat digunakan dalam proses pengambilan keputusan puskesmas terkait dengan penanganan covid-19 yaitu dengan memberikan perhatian khusus dalam penanganan covid di daerah tersebut. Selain pihak internal adapun pihak eksternal yang menggunakan informasi surveilans ini seperti Direktur Rumah Sakit, kader, kepolisian, camat, dan TNI. Pihak eksternal membutuhkan informasi ini untuk menjadi acuan dalam memagari diri dan membatasi aktivitas masyarakat agar masyarakat bisa lebih waspada dalam penyebaran virus covid-19. Disisi lain pihak eksternalal terutama TNI Polri menggunakan hasil surveilans sebagai bahan pengambil keputusan untuk menentukan daerah yang membutuhkan penjagaan.

Secara keseluruhan apek input dalam kegiatan surveilans pada Puskesmas Buleleng I sudah disiapkan dengan baik. Pendekatan input dalam kegiatan surveilans epidemiologi yang terdiri dari man, method, money, material-machine, dan market sudah menunjang aktivitas surveilans. Seperti halnya sumber daya manusia yaitu petugas surveilans yang dipilih oleh Puskesmas Buleleng I wajib sudah mendapatkan pembelajaran atau pelatihan tentang surveilans covid-19 serta mendapatkan orientasi langsung dari Kemenkes secara virtual tentang surveilans covid-19. Kuantitas petugas 
surveilans sudah memadai namun berkaitan dengan kualitas/ kualifikasinya belum sesuai karena tidak memiliki pendidikan dasar epidemologi. Kurangnya kuantitas dan kualitas surveilans epidemologi juga dihasilkan dalam penelitian [22][23]. Yang perlu diperhatikan jugaterkait sumber daya manusia adalah optimalisasi kerja surveilans kedepan agar tidak ada hambatan pelaporan.

Hasil penelitian yang sama juga menunjukkan bahwa petugas surveilans kekurangan tenaga Epidemiologi Ahli (S2) dan Tenaga Epidemiologi Ahli/Terampil (S1) di Bandar Udara Internasional Hang Nadim. Surveilans memiliki kekurangan sarana jaringan elektromedia, telepon dan roda dua. Sementara pada proses sudah memenuhi standar lebih dari 80\% dari indikator Penyelenggaraan Sistem Surveilans Epidemiologi Kesehatan dan output berupa pelaporan telah dilakukan tepat waktu [24]. Hasil penelitian yang sama juga disampaikan bahwa pelaksanaan sistem surveilans Covid-19 di Bandar Udara Internasional Sam Ratulangi Manado sudah berjalan namun belum memenuhi pedoman pelaksanaan yang ada. Perlu dilakukan upaya penyebarluasan informasi, sosialisasi dan penyediaan SDM dan sarana prasaran yang lebih baik [25].

\section{KESIMPULAN}

Berdasarkan hasil dan pembahasan maka dapat ditarik kesimpulan secara keseluruhan kegiatan surveilans epidemiologi terdiri atas $5 \mathrm{M}$ (man, method, money, material-machine, dan market). Puskesmas Buleleng I belum sesuai dengan Peraturan Menteri Kesehatan Republik Indonesia Nomor 45 Tahun 2014 tentang Penyelenggaraan Sistem Surveilans Kesehatan.Ketersediaan epidemiolog terampil belum terpenuhi sesuai dengan pedoman penyelenggaraan sistem surveilans kesehatan. Sehingga peneliti mengharapkan adanya penelitian kembali terkait topik dan pembahasan yang serupa sehingga dapat menemukan kajian yang lebih terkait evaluasi surveilans covid-19 di seluruh Puskesmas yang ada di Kabupaten Buleleng.

\section{UCAPAN TERIMA KASIH}

Ucapan terima kasih kami sampaikan kepada semua pihak yang telah membantu kelancaran penelitian, baik itu kepada Bapak Kepala Puskesmas Buleleng I Kabupaten Buleleng yang telah memberikan kesempatan untuk melakukan penelitian ini. Ucapan 
terimakasih juga kami ucapkan kepada pihak informan (tenaga Surveilans dan tenaga Tracer) yang selalu terbuka dalam menjawab wawancara kami.

\section{DAFTAR RUJUKAN}

[1] WHO, "Coronavirus disease (COVID-19) pandemic," https://www.who.int/emergencies/diseases/novel-coronavirus-2019, 2020. .

[2] Pemerintah Provinsi Bali, "Provinsi Bali Tanggap Covid-19," https://infocorona.baliprov.go.id/, 2020. .

[3] Satgas Covid-19, "Info Covid-19 Buleleng." 2020," http://infocovid19.bulelengkab.go.id/, 2020. .

[4] R. Ramadhan, "Analisis Sistem Surveilans Covid-19 di Wilayah Kerja Kantor Kesehatan Pelabuhan Kelas II Padang Tahun 2020.”Universitas Andalas, 2021.

[5] Y. T. P. S. Barimbing, "Langkah-Langkah Strategi Pemerintah Kecamatan Dalam Pencegahan Penyebaran Covid-19 Di Kecamatan Habinsaran Kabupaten Toba," 2020 .

[6] P. S. Akbar, S. K. Parinduri, and R. Hidana, "Gambaran Pelaksanaan Surveilans Epidemiologi Di Rumah Sakit Umum Daerah Leuwiliang Kabupaten Bogor Tahun 2018," PROMOTOR, vol. 2, no. 5, pp. 410-421, 2019.

[7] R. Rasmaniar et al., Surveilans Kesehatan Masyarakat. Yayasan Kita Menulis, 2020 .

[8] D. Arwanti, "Pelaksanaan surveilans epidemiologi di puskesmas se-Kota Kendari tahun 2016," (Jurnal Ilm. Mhs. Kesehat. Masyarakat), vol. 1, no. 3, 2016.

[9] F. F. Polak et al., "Evaluasi Pelaksanaan Surveilans Corona Virus Disease 2019 di Bandar Udara Internasional Sam Ratulangi Manado tahun 2020,” Indones. J. Public Heal. Community Med., vol. 1, no. 3 Juli, pp. 55-61, 2020.

[10] Kementerian Kesehatan RI, Pedoman Pencegahan dan Pengendalian Coronavirus Disease (COVID-19) - REV 5. Jakarta: Kementerian Kesehatan Republik Indonesia, 2020 .

[11] J. E. Nelwan, Surveilans Kesehatan Masyarakat: Suatu Pengantar. Insan Cendekia Mandiri, 2020.

[12] I. M. Ayu, R. Handayani, and N. W. Sangadji, "SOSIALISASI SURVEILANS DALAM MENGHADAPI COVID-19 GELOMBANG KE-2.”

[13] M. Pane and C. Windyaningsih, "Pedoman Teknis Surveilans Epidemiologi 
Dipuskesmas Dan Dinas Kesehatan Dalam Pengendalian Pandemi Covid-19,” 2020.

[14] I GUSTI AGUNG PUTU MAHENDRAYASA, "Evaluasi Sistem Surveilans Japanese Encephalitis Berdasarkan Atribut Surveilans Di Dinas Kesehatan Provinsi Bali," Dr. Diss. Univ. Airlangga, p. 2015, 2019.

[15] A. M. Ersanti, A. Nugroho, and A. C. Hidajah, "Gambaran kualitas sistem surveilans TB di Dinas Kesehatan Kabupaten Gresik berdasarkan pendekatan sistem dan penilaian atribut,” J. Inf. Syst. Public Heal., vol. 1, no. 2, pp. 9-15, 2017.

[16] E. Rahmayanti and A. Hargono, "IMPLEMENTASI SURVEILANS FAKTOR RISIKO PENYAKIT TIDAK MENULAR BERBASIS POSBINDU BERDASARKAN ATRIBUT,” 2017.

[17] R. D. Anggraini, C. U. W, W. K. Bambang, J. Wiyata, and V. N. Tahun, “KABUPATEN BANGKALAN EVALUATION OF MEASLES SURVEILANCE SYSTEM IN THE HEALTH OFFICE OF BANGKALAN penyakit yang menjadi perhatian dunia dan diikuti oleh semua negara Hal ini dikarenakan menular dan sebagai penyebab utama Health Organization ( WHO ) dan Unite,” Wiyata, vol. 3, no. 2, pp. 174-186, 2016.

[18] S. R. VEBRILIAN, "Evaluasi Sistem Surveilans Infeksi Nosokomial Catheter Associated Urinary Tract Infection di RSU Haji Surabaya," Dr. Diss. Univ. Airlangga, 2016.

[19] Kemenkes RI, Penyelenggaraan Sistem Surveilans Kesehatan. PERATURAN MENTERI KESEHATAN REPUBLIK INDONESIA NOMOR 45 TAHUN 2014. Jakatra, 2014.

[20] L. J. Moleong, Metodologi Penelitian Kualitatif Edisi Revisi”. 2014.

[21] S. Sugiyono, Metode penelitian kuantitatif dan kualitatif dan R\&D. Alfabeta Bandung, 2016.

[22] R. Saputra, A. Alamsyah, and Y. Devita, "PEMANTAUAN SURVEILANS PROGRAM MALARIA DALAM MEMPERTAHANKAN SERTIFIKASI ELIMINASI DI KABUPATEN ROKAN HULU," Al-Tamimi Kesmas J. Ilmu Kesehat. Masy. (Journal Public Heal. Sci., vol. 9, no. 2, pp. 131-150, 2020.

[23] D. P. Sari, "Evaluasi Surveilans Epidemiologi Demam Berdarah Dengue (DBD) di Puskesmas Pudakpayung Semarang Tahun 2018," J. Ilmu Kesehat. Masy. Berk., vol. 2, no. 1, pp. 23-31, 2020.

[24] Siregar PA, "Manajemen surveilans Covid-19 di wilayah kerja Bandar Udara 
Internasional Hang Nadim.," Jhecds, vol. 6, no. 2, pp. 73-81, 2020.

[25] Polak FF, "Evaluasi Pelaksanaan Surveilans Corona Virus Disease 2019 di Bandar Udara Internasional Sam Ratulangi Manado tahun 2020,” Indones J Public Heal Community Med, vol. 1, pp. 55-61, 2020. 